\title{
Chaetognatha of the Brazil-Malvinas (Falkland) confluence: distribution and associations
}

\author{
Alina M. Crelier \& María C. Daponte \\ Departamento de Biodiversidad y Biología Experimental, Facultad de Ciencias Exactas y Naturales, Universidad de Buenos Aires, \\ Pab. II, Ciudad Universitaria, C1428EHA, Buenos Aires, Argentina. (daponte@bg.fcen.uba.ar)
}

\begin{abstract}
The planktonic chaetognaths from the Brazil-Malvinas (Falkland) confluence, extending between $36^{\circ} 30^{\prime}-50^{\circ} 5^{\prime} \mathrm{S}$ and $60^{\circ} 33^{\prime}-41^{\circ} 7^{\prime} \mathrm{W}$, were studied. Ten species were found: Eukrohnia hamata (Möbius, 1875) (Eukrohniidae), Pterosagitta draco (Krohn, 1853) (Pterosagittidae), Sagitta enflata Grassi, 1881, Sagitta gazellae Ritter-Zahony, 1909, Sagitta hexaptera d'Orbigny, 1834, Sagitta lyra Krohn, 1853, Sagitta minima Grassi, 1881, Sagitta planctonis Steinhaus, 1896, Sagitta serratodentata Krohn, 1853, and Sagitta tasmanica Thomson, 1947 (Sagittidae). Sagitta gazellae was the most abundant species followed by E. hamata, S. tasmanica and S. serratodentata. The association analysis among the different species, salinity and temperature revealed two groups of species, one related to higher salinities and warmer waters ( $P$. draco, $S$. hexaptera and $S$. serratodentata) and the other to lower salinities and colder waters (E. hamata, S. gazellae and S. tasmanica). The fact that $P$. draco and S. hexaptera, formerly defined as warm-water species, appeared further south than previously reported might be related to the existence of warm core eddies up to $46^{\circ} \mathrm{S}$ in September and October 1988.
\end{abstract}

KEYWORDS. Eukrohniidae, Pterosagittidae, Sagittidae, southwestern Atlantic, zooplankton.

\section{INTRODUCTION}

Chaetognaths are important members of the marine pelagic community; their biomass has been estimated in $30 \%$ of that of copepods (REEVE, 1970), and their energy transference to higher trophic levels is considered expressive (FeingenBaum, 1991), since they constitute a trophic link between the high number of copepods and larger predators. They can be found in all oceans, from bottom to surface waters, and their horizontal distribution can be affected, among other factors, by changes in the currents, salinity, and temperature. Chaetognaths have become useful as hydrological indicators due to their affinity for specific water types (BoltovsкoY, D., 1981; Mazzoni, 1983; McLelland, 1984). As a rule, each water mass contains characteristic planktonic species, which can determine faunistic differences between neighboring areas. The existing information on the distribution and abundance of the different species of chaetognaths depends on the oceanographic regions considered. In the Southwestern Atlantic Ocean most of the studies were carried out in different areas of the continental shelf (Almeida Prado, 1961a, b, 1963, 1968; Mostajo, 1973, 1976; MAZzoni, 1983) or near the slope (Boltovskoy \& Mostajo, 1974; Boltovskoy, D., 1975a,b, 1981). On the other hand, the investigations accomplished off the continental slope were sparse (BoLLMANN, 1934; THIEL, 1938), and the extensive distance between sampling stations has prevented a detailed analysis of the distribution of these organisms, mainly in hydrologically complex oceanic areas.

The present study aims to analyze the planktonic chaetognaths found in the Brazil-Malvinas (Falkland) confluence, where tropical and cold-water faunas converge. The composition and distribution of chaetognath associations were determined and their relations to surface salinity and water temperature investigated.

\section{MATERIAL AND METHODS}

Hydrology of the area. The surveyed area has a complex hydrological structure, characterized by the presence of different water masses and currents. Subantarctic waters are carried from the south in a northnortheastward direction along the Patagonian Shelf by the Malvinas (Falkland) Current (MC), a branch of the West Wind Drift (WWD) (Peterson \& Stramma, 1991; Piola \& Rivas, 1997), whereas the northern area is influenced by the tropical-subtropical waters of the Brazil Current (BC) (fig. 1). The WWD is constituted by pure and typical Subantarctic waters, with a minimum winter temperature of $3.5^{\circ} \mathrm{C}$ and a minimum summer temperature of $5.5^{\circ} \mathrm{C}$ (Boltovskoy, E., 1970, 1981). The MC is characterized by salinities between 34 and 34.5 psu and temperatures below $10-11{ }^{\circ} \mathrm{C}$ (Goni et al., 1996; Provost et al., 1996; GuerRERo \& Piola, 1997). However, its surface temperature depends on latitude and season (BоLтоvsкоY, E., 1970, 1981; LEGECKIS \& GoRDON, 1982). BC waters reach temperatures higher than $20^{\circ} \mathrm{C}$ and salinities over $36 \mathrm{psu}$ (Thomsen, 1962; Boltovskoy, 1970; Brandhorst \& Castello, 1971; Ciotti et al., 1995; Goni et al., 1996; PRovost et al., 1996). In its southern boundary, $\mathrm{BC}$ waters converge turbulently with the colder and less saline Subantarctic waters, loosing thereby warmth and salinity (Peterson \& Stramma, 1991) and giving rise to the Brazil-Malvinas (Falkland) confluence zone (BMCZ). The $\mathrm{BMCZ}$ is highly complex because of the presence of warm core eddies and meanders (Boltovskoy, E., 1970, 1981; LEGECKIS \& GORDON, 1982; GoRDON, 1989). Their position oscillates between $38^{\circ}$ and $46^{\circ} \mathrm{S}$, depending on the season (LEGECKIS \& GORDON, 1982).

The Subantarctic front (SAF) marks the southern limit of Subantarctic waters. Near Malvinas Plateau, the SAF sharply turns northward and reaches the BMCZ, then turns southward to finally deflect eastwards. 
Sampling design and data processing. The plankton samples were obtained by the Russian Research Vessel RTMA “EVRIKA" from August $1^{\text {st }}$ through October $24^{\text {th }}$, 1988 , in an oceanic sector located between $36^{\circ} 30^{\prime}-50^{\circ} 5^{\prime} \mathrm{S}$ and $60^{\circ} 33^{\prime}-41^{\circ} 7^{\prime} \mathrm{W}$. Oblique tows were taken from $50 \mathrm{~m}$ of depth to surface with a Bongo net of $60 \mathrm{~cm}$ of mouth diameter and $500 \mu \mathrm{m}$ mesh. The filtered volume was determined with a digital DF-2030 flowmeter. Surface water temperature and salinity were registered in each station. The samples were fixed in $4 \%$ formaldehyde and deposited in the collection of the Department of Biodiversity and Experimental Biology, Universidad de Buenos Aires.

All chaetognaths were identified according to Casanova (1999). Density of the species found in each station was calculated as individuals $1000 \mathrm{~m}^{-3}$. The length and width of the smallest specimens collected with the net were measured. Horizontal distribution and abundance patterns were determined for each species, and their relationships with surface water temperature and salinity analyzed.

Similarities among sample units (s.u.) having chaetognaths were studied using Ochiai qualitative coefficient and Bray-Curtis quantitative index (LEGENDRE \& LEGENDRE, 1998). The values obtained were grouped through the unweighted arithmetic average clustering method (UPGMA) (LegENDRE \& LegendRe, 1998). The greatest distance among clusters in the successive agglomeration steps was considered as the reference level (HaIr et al., 1992). The results obtained from both indexes were compared with an exact test for $3 \times 3$ contingency tables (Digby \& Kempton, 1994). In accordance to the clusters defined through the Ochiai index and UPGMA, the percentage of species present in each group was analyzed, and the fidelity degree of each species to each group (ZAIXso, 1996) evaluated with a contingency table, using an $\mathrm{RxC}$ independence $\mathrm{G}$ test or a Fisher two tails exact test when any of the expected values was smaller than five (SoKaL \& RoHLF, 1997). The preferential species of a group were defined as those positively and significantly associated to it $(\mathrm{p}<0.05)$. The indicator species were defined as those preferential ones present in at least $75 \%$ of the s.u. in the group. The exclusive species were defined as those having a $100 \%$ fidelity degree to a group (ZAIXso, 1996).

Relationships among temperature, salinity and clusters (Ochiai-UPGMA) were studied through correspondence factorial analysis (BENZECRI, 1976; GAUCH, 1989) on a contingency table of groups and environmental factors (Legendre \& Legendre, 1998; Carrasco \& HERNÁN, 1993). Three temperature intervals were defined for this analysis: temperature $1(\operatorname{tem} 1)$ from $3^{\circ}$ to $8^{\circ} \mathrm{C}$, temperature 2 (tem 2 ) from $8^{\circ}$ to $13^{\circ} \mathrm{C}$, and temperature 3 (tem3) from $13{ }^{\circ}$ to $18{ }^{\circ} \mathrm{C}$. Three salinity intervals were also defined: salinity 1 (sal1) from 33.5 to $34.6 \mathrm{psu}$, salinity 2 (sal2) from 34.6 to 35.4 psu, and salinity 3 (sal3) from 35.4 to 36.2 psu.

\section{RESULTS AND DISCUSSION}

Chaetognaths were found in 70 out of 110 oceanographic stations. Only those samples containing well-preserved specimens were considered $(n=63)$. The species found in the study area were: Eukrohnia hamata (Möbius, 1875) (Eukrohniidae), Pterosagitta draco (Krohn, 1853) (Pterosagittidae), Sagitta enflata Grassi, 1881, Sagitta gazellae Ritter-Zahony, 1909, Sagitta hexaptera d'Orbigny, 1834, Sagitta lyra Krohn, 1853, Sagitta minima Grassi, 1881, Sagitta planctonis Steinhaus, 1896, Sagitta serratodentata Krohn, 1853, and Sagitta tasmanica Thomson, 1947 (Sagittidae) (tab. I). Sagitta gazellae was the most frequent (45\%), followed by S. serratodentata (20\%), S. hexaptera (19.1\%), P. draco (18.25\%), and S. tasmanica (15.5\%). The most abundant species were $S$. gazellae (up to 1062 ind. $1000 \mathrm{~m}^{-3}$ ), E. hamata (788 ind. $\left.1000 \mathrm{~m}^{-3}\right)$, S. tasmanica (153 ind. $1000 \mathrm{~m}^{-3}$ ), and S. serratodentata (up to 73 ind. $1000 \mathrm{~m}^{-3}$ ) (figs. 2, 3). The densities of P. draco, S. lyra, S. minima, $S$. enflata, S. hexaptera and S. planctonis were lower than 55 ind. $1000 \mathrm{~m}^{-3}$ (figs. 4, 5).

The net probably failed to catch specimens having maximum diameter smaller than $500 \mu \mathrm{m}$. Such diameter corresponds to total lengths $<7.5 \mathrm{~mm}(\mathrm{n}=15)$ for S. minima and up to $35 \mathrm{~mm}$ for $S$. gazellae $(\mathrm{n}=100)$.

Sagitta gazellae was found all over the sampling area, being most abundant between 40 and $50^{\circ} \mathrm{S}$ and having low densities between $36^{\circ} 30^{\prime}$ and $39^{\circ} \mathrm{S}$. The northern area, which presented the lowest densities, was warmer $\left(13^{\circ}-15.2^{\circ} \mathrm{C}\right)$ and more saline $(35-35.7$ psu). High densities were found at temperatures between $3.6{ }^{\circ} \mathrm{C}$ and $13.0^{\circ} \mathrm{C}$ and salinities between 34 and 35 psu (fig. 6). These values are typical of Subantarctic waters and fall within the limits reported in the literature (DAviD, 1955). The low densities of $S$. gazellae in the northern area may reflect certain environmental conditions (salinity $>35.0 \mathrm{psu}$ ) that are unsuitable for the development of this species.

Eukrohnia hamata was found south of $42^{\circ} \mathrm{S}$. The temperature-salinity-density diagram (T-S-D) shows the highest abundances at $3.6^{\circ}-8.7^{\circ} \mathrm{C}$ and 34 - 34.4 psu (fig. 6), corresponding to the location of the WWD (fig. 1). Its absence northward may indicate its sinking to deeper layers at these latitudes, according to its mesoplanktonic nature at intermediate latitudes (Pierrot-Bults \& Nair, 1991).

Sagitta tasmanica extends northward up to $38^{\circ} 50^{\prime} \mathrm{S}$, at temperatures of $5^{\circ}-14.6^{\circ} \mathrm{C}$ and salinities of $34.1-35.1 \mathrm{psu}$ (fig. 7). The highest densities were found between 7.8 and $10.0^{\circ} \mathrm{C}$, and between 34.4 and $34.6 \mathrm{psu}$. The highest salinities correspond to mixed waters, thus indicating certain tolerance of this species to warmer conditions. DADON \& Boltovsкoy (1982) also reported the presence of $S$. tasmanica in transitional waters that reach the northern boundary of the BMCZ.

Sagitta serratodentata was found at temperature and salinity ranges oscillating between 9.1 and $16.7^{\circ} \mathrm{C}$ and between 34.5 and 35.9 psu (fig. 7), whereas the highest densities and frequencies were found at temperatures and salinities above $14{ }^{\circ} \mathrm{C}$ and $35.0 \mathrm{psu}$.

Pterosagitta draco was found at temperatures ranging between 6.7 and $16.7^{\circ} \mathrm{C}$, and salinities between 34.1 and 35.9 psu (fig. 8). However, in agreement with the authors who characterized it as a warm-water species (Grant, 1991; Liang \& Vega-Pérez, 2001), the 
Table I. Oceanographic data and planktonic chaetognath species found in each sampling station of Russian Research Vessel RTMA "EVRIKA" from Brazil-Malvinas (Falkland) confluence, August $1^{\text {st }}$ through October 24 $4^{\text {th }}, 1988$ (Eh, E. hamata; Pd, P. draco; Se, S. enflata; Sg, S. gazellae; Sh, S. hexaptera; Sl, S. lyra; Sm, S. minima; Sp, S. planctonis; Ss, S. serratodentata; St, S. tasmanica).

\begin{tabular}{|c|c|c|c|c|c|c|}
\hline \multirow{2}{*}{$\frac{\text { Station }}{1}$} & \multirow{2}{*}{$\begin{array}{l}\text { Date } \\
01 / 08\end{array}$} & \multicolumn{2}{|c|}{ Position } & \multirow{2}{*}{$\frac{\text { Temperature }\left({ }^{\circ} \mathrm{C}\right)}{14.00}$} & \multirow{2}{*}{$\begin{array}{c}\text { Salinity (psu) } \\
35.19\end{array}$} & \multirow{2}{*}{$\frac{\text { Species }}{\mathrm{Pd}, \mathrm{Sg}, \mathrm{Sh}, \mathrm{Ss}}$} \\
\hline & & $36^{\circ} 30^{\prime} \mathrm{S}$ & $50^{\circ} 31^{\prime} \mathrm{W}$ & & & \\
\hline 2 & $02 / 08$ & $36^{\circ} 30^{\prime} \mathrm{S}$ & $49^{\circ} 51^{\prime} \mathrm{W}$ & 12.64 & 34.53 & $\mathrm{Pd}, \mathrm{Se}, \mathrm{Sg}, \mathrm{Sh}, \mathrm{Ss}$ \\
\hline 4 & $03 / 08$ & $36^{\circ} 30^{\prime} \mathrm{S}$ & $48^{\circ} 30^{\prime} \mathrm{W}$ & 16.66 & 35.91 & $\mathrm{Pd}, \mathrm{Sh}, \mathrm{Sp}, \mathrm{Ss}$ \\
\hline 5 & 03/08 & $36^{\circ} 56^{\prime} \mathrm{S}$ & $47^{\circ} 57^{\prime} \mathrm{W}$ & 15.63 & 35.73 & $\mathrm{Pd}, \mathrm{Sh}$ \\
\hline 6 & $03 / 08$ & $37^{\circ} 30^{\prime} \mathrm{S}$ & $47^{\circ} 30^{\prime} \mathrm{W}$ & 15.06 & 35.59 & Sg, Sh, Ss \\
\hline 7 & $04 / 08$ & $37^{\circ} 27^{\prime} \mathrm{S}$ & $48^{\circ} 01^{\prime} \mathrm{W}$ & 15.20 & 35.67 & $\mathrm{Pd}, \mathrm{Sg}, \mathrm{Sh}, \mathrm{Ss}$ \\
\hline 8 & $04 / 08$ & $37^{\circ} 30^{\prime} \mathrm{S}$ & $48^{\circ} 30^{\prime} \mathrm{W}$ & 14.80 & 35.65 & $\mathrm{Sh}$ \\
\hline 9 & $04 / 08$ & $37^{\circ} 30^{\prime} \mathrm{S}$ & $49^{\circ} 44^{\prime} \mathrm{W}$ & 14.74 & 35.56 & $\mathrm{Pd}, \mathrm{Sh}, \mathrm{Sm}, \mathrm{Ss}$ \\
\hline 10 & $04 / 08$ & $37^{\circ} 31^{\prime} \mathrm{S}$ & $50^{\circ} 59^{\prime} \mathrm{W}$ & 14.03 & 35.36 & $\mathrm{Pd}, \mathrm{Sg}, \mathrm{Sh}, \mathrm{Sp}, \mathrm{Ss}$ \\
\hline 11 & $05 / 08$ & $37^{\circ} 30^{\prime} \mathrm{S}$ & $51^{\circ} 30^{\prime} \mathrm{W}$ & 14.64 & 35.53 & $\mathrm{Pd}, \mathrm{Sg}, \mathrm{Sh}, \mathrm{Ss}$ \\
\hline 12 & $05 / 08$ & $37^{\circ} 30^{\prime} \mathrm{S}$ & $51^{\circ} 52^{\prime} \mathrm{W}$ & 14.81 & 35.60 & $\mathrm{Pd}, \mathrm{Sg}, \mathrm{Sh}, \mathrm{Ss}$ \\
\hline 14 & $05 / 08$ & $38^{\circ} 50^{\prime} \mathrm{S}$ & $53^{\circ} 09^{\prime} \mathrm{W}$ & 12.20 & 34.83 & St \\
\hline 16 & $06 / 08$ & $39^{\circ} 00^{\prime} \mathrm{S}$ & $53^{\circ} 00^{\prime} \mathrm{W}$ & 14.79 & 35.65 & Sh \\
\hline 17 & $06 / 08$ & $39^{\circ} 00^{\prime} \mathrm{S}$ & $52^{\circ} 08^{\prime} \mathrm{W}$ & 14.70 & 35.56 & Sh \\
\hline 19 & $07 / 08$ & $39^{\circ} 00^{\prime} \mathrm{S}$ & $50^{\circ} 43^{\prime} \mathrm{W}$ & 15.00 & 35.70 & $\mathrm{Sh}, \mathrm{Ss}$ \\
\hline 20 & $07 / 08$ & $39^{\circ} 00^{\prime} \mathrm{S}$ & $50^{\circ} 10^{\prime} \mathrm{W}$ & 15.06 & 35.66 & $\mathrm{Pd}, \mathrm{Sg}, \mathrm{Sh}, \mathrm{Sm}, \mathrm{Ss}$ \\
\hline 21 & $07 / 08$ & $39^{\circ} 01^{\prime} \mathrm{S}$ & $49^{\circ} 18^{\prime} \mathrm{W}$ & 15.09 & 35.76 & $\mathrm{Sh}$ \\
\hline 23 & $08 / 08$ & $39^{\circ} 00^{\prime} \mathrm{S}$ & $48^{\circ} 00^{\prime} \mathrm{W}$ & 14.74 & 35.69 & $\mathrm{Pd}, \mathrm{Sh}, \mathrm{Ss}$ \\
\hline 24 & $08 / 08$ & $39^{\circ} 00^{\prime} \mathrm{S}$ & $47^{\circ} 30^{\prime} \mathrm{W}$ & 12.78 & 35.27 & $\mathrm{Pd}, \mathrm{Sg}, \mathrm{Ss}$ \\
\hline 27 & $08 / 08$ & $39^{\circ} 00^{\prime} \mathrm{S}$ & $47^{\circ} 17^{\prime} \mathrm{W}$ & 10.43 & 34.69 & $\mathrm{Sg}$ \\
\hline 29 & $11 / 08$ & $40^{\circ} 18^{\prime} \mathrm{S}$ & $44^{\circ} 12^{\prime} \mathrm{W}$ & 11.78 & 35.03 & $\mathrm{Sg}, \mathrm{St}$ \\
\hline 32 & $11 / 08$ & $40^{\circ} 28^{\prime} \mathrm{S}$ & $44^{\circ} 53^{\prime} \mathrm{W}$ & 14.27 & 35.59 & $\mathrm{Pd}, \mathrm{Sh}, \mathrm{Ss}$ \\
\hline 33 & $12 / 08$ & $40^{\circ} 28^{\prime} \mathrm{S}$ & $45^{\circ} 57^{\prime} \mathrm{W}$ & 11.20 & 34.90 & $\mathrm{Sg}, \mathrm{Ss}$ \\
\hline 34 & $13 / 08$ & $40^{\circ} 30^{\prime} \mathrm{S}$ & $47^{\circ} 00^{\prime} \mathrm{W}$ & 9.78 & 34.64 & $\mathrm{Pd}, \mathrm{Sg}, \mathrm{Ss}$ \\
\hline 37 & $16 / 08$ & $40^{\circ} 29^{\prime} \mathrm{S}$ & $50^{\circ} 29^{\prime} \mathrm{W}$ & 9.38 & 34.45 & $\mathrm{Pd}, \mathrm{Sg}$ \\
\hline 39 & $17 / 08$ & $40^{\circ} 28^{\prime} \mathrm{S}$ & $51^{\circ} 44^{\prime} \mathrm{W}$ & 14.35 & 35.49 & $\mathrm{Se}, \mathrm{Sg}, \mathrm{Ss}$ \\
\hline 40 & $17 / 08$ & $40^{\circ} 30^{\prime} \mathrm{S}$ & $52^{\circ} 40^{\prime} \mathrm{W}$ & 14.50 & 35.58 & $\mathrm{Sg}, \mathrm{Sh}, \mathrm{Ss}$ \\
\hline 42 & $18 / 08$ & $40^{\circ} 29^{\prime} \mathrm{S}$ & $54^{\circ} 27^{\prime} \mathrm{W}$ & 7.00 & 34.11 & $\mathrm{Sg}$ \\
\hline 46 & $21 / 08$ & $41^{\circ} 58^{\prime} \mathrm{S}$ & $55^{\circ} 27^{\prime} \mathrm{W}$ & 6.22 & 34.05 & $\mathrm{Sg}$ \\
\hline 47 & $22 / 08$ & $42^{\circ} 00^{\prime} \mathrm{S}$ & $54^{\circ} 30^{\prime} \mathrm{W}$ & 6.96 & 34.09 & $\mathrm{Eh}, \mathrm{Pd}, \mathrm{Sg}, \mathrm{St}$ \\
\hline 50 & $23 / 08$ & $42^{\circ} 00^{\prime} \mathrm{S}$ & $51^{\circ} 37^{\prime} \mathrm{W}$ & 9.30 & 34.32 & $\mathrm{Sg}$ \\
\hline 51 & $23 / 08$ & $42^{\circ} 00^{\prime} \mathrm{S}$ & $50^{\circ} 30^{\prime} \mathrm{W}$ & 9.37 & 34.50 & $\mathrm{Sg}, \mathrm{St}$ \\
\hline 52 & $23 / 08$ & $42^{\circ} 00^{\prime} \mathrm{S}$ & $49^{\circ} 35^{\prime} \mathrm{W}$ & 9.85 & 34.60 & $\mathrm{Sg}, \mathrm{St}$ \\
\hline 53 & $24 / 08$ & $41^{\circ} 58^{\prime} \mathrm{S}$ & $48^{\circ} 31^{\prime} \mathrm{W}$ & 14.35 & 35.55 & $\mathrm{Sg}, \mathrm{Ss}$ \\
\hline 55 & $25 / 08$ & $42^{\circ} 00^{\prime} \mathrm{S}$ & $45^{\circ} 00^{\prime} \mathrm{W}$ & 9.05 & 34.57 & $\mathrm{Sg}, \mathrm{Ss}$ \\
\hline 61 & $04 / 09$ & $47^{\circ} 30^{\prime} \mathrm{S}$ & $54^{\circ} 33^{\prime} \mathrm{W}$ & 5.83 & 34.24 & $\mathrm{Sg}$ \\
\hline 62 & $04 / 09$ & $45^{\circ} 59^{\prime} \mathrm{S}$ & $54^{\circ} 28^{\prime} \mathrm{W}$ & 6.13 & 34.14 & $\mathrm{Sg}$ \\
\hline 66 & $06 / 09$ & $45^{\circ} 59^{\prime} \mathrm{S}$ & $58^{\circ} 31^{\prime} \mathrm{W}$ & 4.32 & 34.07 & $\mathrm{Sg}$ \\
\hline 69 & 06/09 & $45^{\circ} 59^{\prime} \mathrm{S}$ & $60^{\circ} 01^{\prime} \mathrm{W}$ & 5.66 & 34.01 & Sg \\
\hline 73 & 08/09 & $45^{\circ} 00^{\prime} \mathrm{S}$ & $59^{\circ} 00^{\prime} \mathrm{W}$ & 4.06 & 34.08 & $\mathrm{Sg}$ \\
\hline 75 & 08/09 & $45^{\circ} 00^{\prime} \mathrm{S}$ & $57^{\circ} 41^{\prime} \mathrm{W}$ & 5.04 & 34.08 & $\mathrm{Sg}, \mathrm{St}$ \\
\hline 77 & 09/09 & $45^{\circ} 00^{\prime} \mathrm{S}$ & $56^{\circ} 38^{\prime} \mathrm{W}$ & 9.04 & 34.60 & $\mathrm{Eh}, \mathrm{Sg}, \mathrm{St}$ \\
\hline 80 & $10 / 09$ & $45^{\circ} 02^{\prime} \mathrm{S}$ & $54^{\circ} 37^{\prime} \mathrm{W}$ & 11.71 & 35.03 & $\mathrm{Pd}, \mathrm{Sp}, \mathrm{St}$ \\
\hline 85 & $11 / 09$ & $43^{\circ} 30^{\prime} \mathrm{S}$ & $50^{\circ} 25^{,} \mathrm{W}$ & 10.72 & 34.91 & $\mathrm{Pd}, \mathrm{Sg}, \mathrm{Sp}$ \\
\hline 86 & $12 / 09$ & $43^{\circ} 29^{\prime} \mathrm{S}$ & $50^{\circ} 52^{\prime} \mathrm{W}$ & 11.74 & 35.12 & $\mathrm{Pd}, \mathrm{Sg}, \mathrm{St}$ \\
\hline 90 & $14 / 09$ & $43^{\circ} 28^{\prime} \mathrm{S}$ & $58^{\circ} 27^{\prime} \mathrm{W}$ & 4.49 & 34.09 & $\mathrm{Sg}$ \\
\hline 91 & $15 / 09$ & $43^{\circ} 26^{\prime} \mathrm{S}$ & $58^{\circ} 59^{\prime} \mathrm{W}$ & 4.62 & 34.12 & $\mathrm{Eh}, \mathrm{Sg}$ \\
\hline 106 & $07 / 10$ & $43^{\circ} 42^{\prime} \mathrm{S}$ & $50^{\circ} 00^{\prime} \mathrm{W}$ & 8.31 & 34.59 & $\mathrm{Sg}, \mathrm{St}$ \\
\hline 107 & $07 / 10$ & $44^{\circ} 29^{\prime} \mathrm{S}$ & $50^{\circ} 00^{\prime} \mathrm{W}$ & 11.39 & 35.10 & $\mathrm{Eh}, \mathrm{Sl}, \mathrm{Ss}$ \\
\hline 108 & $07 / 10$ & $45^{\circ} 09^{\prime} \mathrm{S}$ & $50^{\circ} 01^{\prime} \mathrm{W}$ & 8.26 & 34.48 & $\mathrm{Sg}, \mathrm{St}$ \\
\hline 109 & $08 / 10$ & $46^{\circ} 10^{\prime} \mathrm{S}$ & $50^{\circ} 02^{\prime} \mathrm{W}$ & 10.96 & 35.00 & $\mathrm{Sg}, \mathrm{Sh}, \mathrm{Sp}$ \\
\hline 111 & $09 / 10$ & $50^{\circ} 00^{\prime} \mathrm{S}$ & $50^{\circ} 01^{\prime} \mathrm{W}$ & 3.71 & 34.05 & $\mathrm{Eh}, \mathrm{Sg}$ \\
\hline 112 & $10 / 10$ & $49^{\circ} 38^{\prime} \mathrm{S}$ & $49^{\circ} 18^{\prime} \mathrm{W}$ & 3.63 & 34.03 & $\mathrm{Eh}, \mathrm{Sg}$ \\
\hline 113 & $10 / 10$ & $49^{\circ} 09^{\prime} \mathrm{S}$ & $48^{\circ} 13^{\prime} \mathrm{W}$ & 6.26 & 34.21 & $\mathrm{Sg}$ \\
\hline 114 & $10 / 10$ & $48^{\circ} 29^{\prime} \mathrm{S}$ & $47^{\circ} 10^{\prime} \mathrm{W}$ & 8.67 & 34.48 & $\mathrm{Eh}, \mathrm{Sg}$ \\
\hline 115 & $11 / 10$ & $47^{\circ} 50^{\prime} \mathrm{S}$ & $46^{\circ} 01^{\prime} \mathrm{W}$ & 7.70 & 34.48 & $\mathrm{Eh}, \mathrm{Sg}, \mathrm{St}$ \\
\hline 118 & $12 / 10$ & $45^{\circ} 01^{\prime} \mathrm{S}$ & $44^{\circ} 59^{\prime} \mathrm{W}$ & 7.84 & 34.41 & $\mathrm{Sg}, \mathrm{St}$ \\
\hline 119 & $12 / 10$ & $43^{\circ} 59^{\prime} \mathrm{S}$ & $45^{\circ} 01^{\prime} \mathrm{W}$ & 8.02 & 34.43 & $\mathrm{Sg}, \mathrm{St}$ \\
\hline 121 & $13 / 10$ & $42^{\circ} 10^{\prime} \mathrm{S}$ & $45^{\circ} 00^{\prime} \mathrm{W}$ & 10.20 & 34.68 & $\mathrm{Sg}, \mathrm{St}$ \\
\hline 122 & $13 / 10$ & $42^{\circ} 29^{\prime} \mathrm{S}$ & $44^{\circ} 57^{\prime} \mathrm{W}$ & 11.80 & 34.87 & $\mathrm{Pd}, \mathrm{Sg}, \mathrm{Sp}, \mathrm{St}$ \\
\hline 123 & $13 / 10$ & $41^{\circ} 01, \mathrm{~S}$ & $45^{\circ} 00^{\prime} \mathrm{W}$ & 11.80 & 34.87 & $\mathrm{Sg}, \mathrm{Sp}, \mathrm{St}$ \\
\hline 124 & $14 / 10$ & $40^{\circ} 27^{\prime} \mathrm{S}$ & $44^{\circ} 58^{\prime}, \mathrm{W}$ & 14.60 & 35.07 & $\mathrm{Sg}, \mathrm{Sh}, \mathrm{Sm}, \mathrm{Sp}, \mathrm{St}$ \\
\hline
\end{tabular}




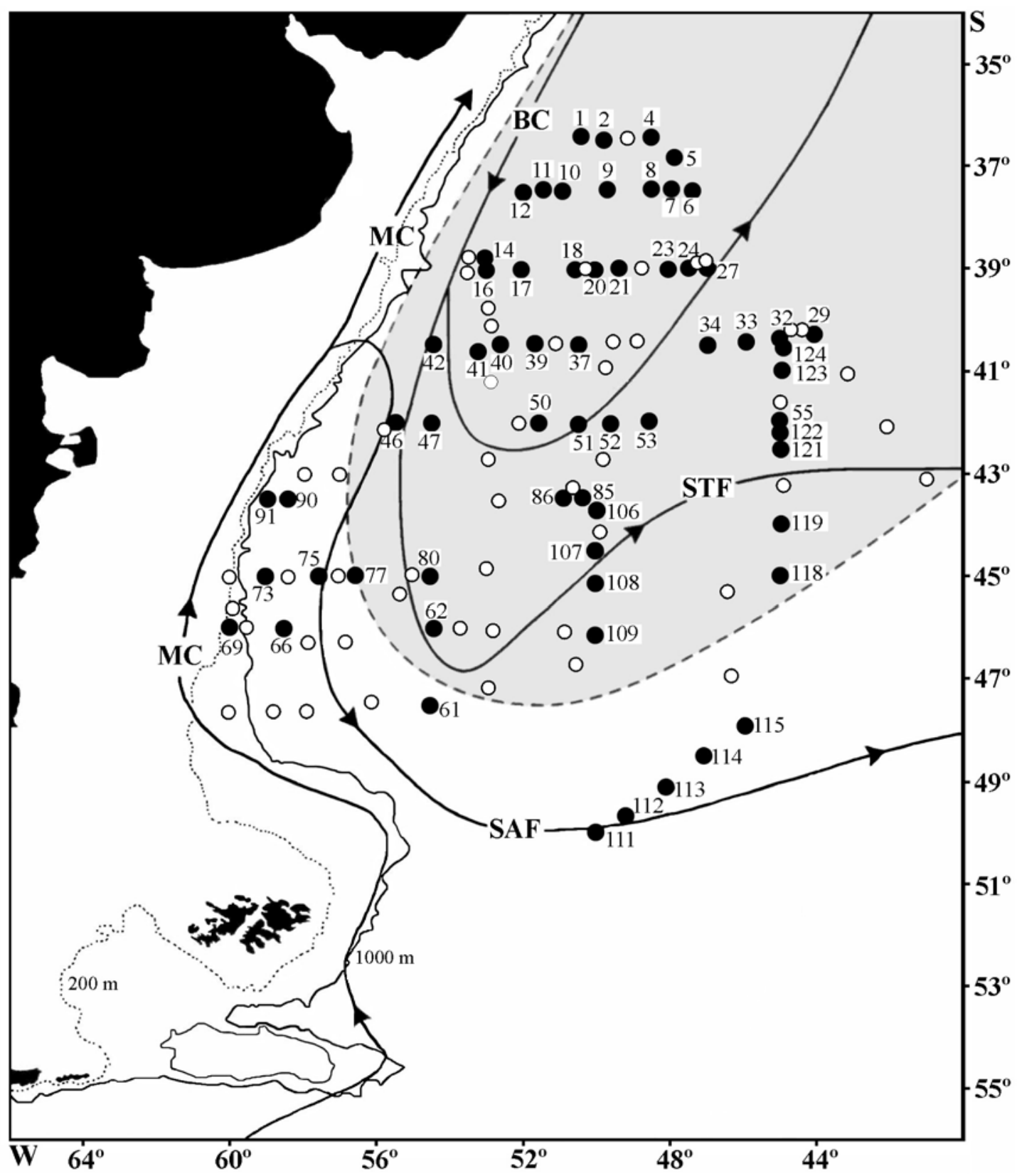

Fig. 1. Schematic representation of the surface hydrology of the surveyed area (adapted from Peterson \& Stramma, 1991) and position of sampling stations of Russian Research Vessel RTMA "EVRIKA" from August, $1^{\text {st }}$ through October, $24^{\text {th }}$, 1988 (BC, Brazil current; MC, Malvinas (Falkland) current; SAF, Subantarctic front; STF, Subtropical Front; Grey area, Brazil-Malvinas (Falkland) confluence; black circles, chaetognath presence; white circles, chaetognath absence.

highest densities were found above $14{ }^{\circ} \mathrm{C}$ and 35.4 psu. Although the boundary of its southern distribution was established at $40^{\circ} \mathrm{S}$ (ALvariño, 1969; Pierrot-Bults \& Nair, 1991), we report its presence up to $45^{\circ} 02^{\prime} \mathrm{S}$.

Sagitta minima appeared in three stations with mixed water characteristics $\left(14-15^{\circ} \mathrm{C}, 35.5-35.6 \mathrm{psu}\right)$ (fig. 8), in agreement with the observations by Alvariño $(1965,1969)$. A low density of Sagitta lyra $\left(9\right.$ ind. $\left.1000 \mathrm{~m}^{-3}\right)$ was found in only one station ( $\left(44^{\circ} 29^{\prime} \mathrm{S}\right)$, at $11.39^{\circ} \mathrm{C}$ and $35.1 \mathrm{psu}$ (fig. 8). Very few specimens of $S$. enflata were found in the study area, in two stations north of $41^{\circ} \mathrm{S}$, at temperatures fluctuating between 12.6 and $14.4{ }^{\circ} \mathrm{C}$ and salinities between 34.5 and 35.5 psu (fig. 8).
Sagitta hexaptera was allocated north of $41^{\circ}$ $\mathrm{S}$, except for one specimen recorded at $46^{\circ} 10^{\prime} \mathrm{S}$, and its densities were low $\left(<16\right.$ ind. $\left.1000^{-3}\right)$. This species generally appeared in mixed waters with subtropical influence $\left(13^{\circ}-16.7^{\circ} \mathrm{C}, 35.4\right.$ - $\left.35.9 \mathrm{psu}\right)$ (fig. 9).

Sagitta planctonis was found in waters at 10.7 $16.7^{\circ} \mathrm{C}$ with salinities of 34.9 - 35.9 psu (fig. 9). The highest temperatures and salinities correspond to the northern stations. The present results confirm the presence of this species over the BMCZ, in the surface layers and in mixed water, especially regarding salinity, which in all of the stations exceeded the typical values for subantarctic waters. 

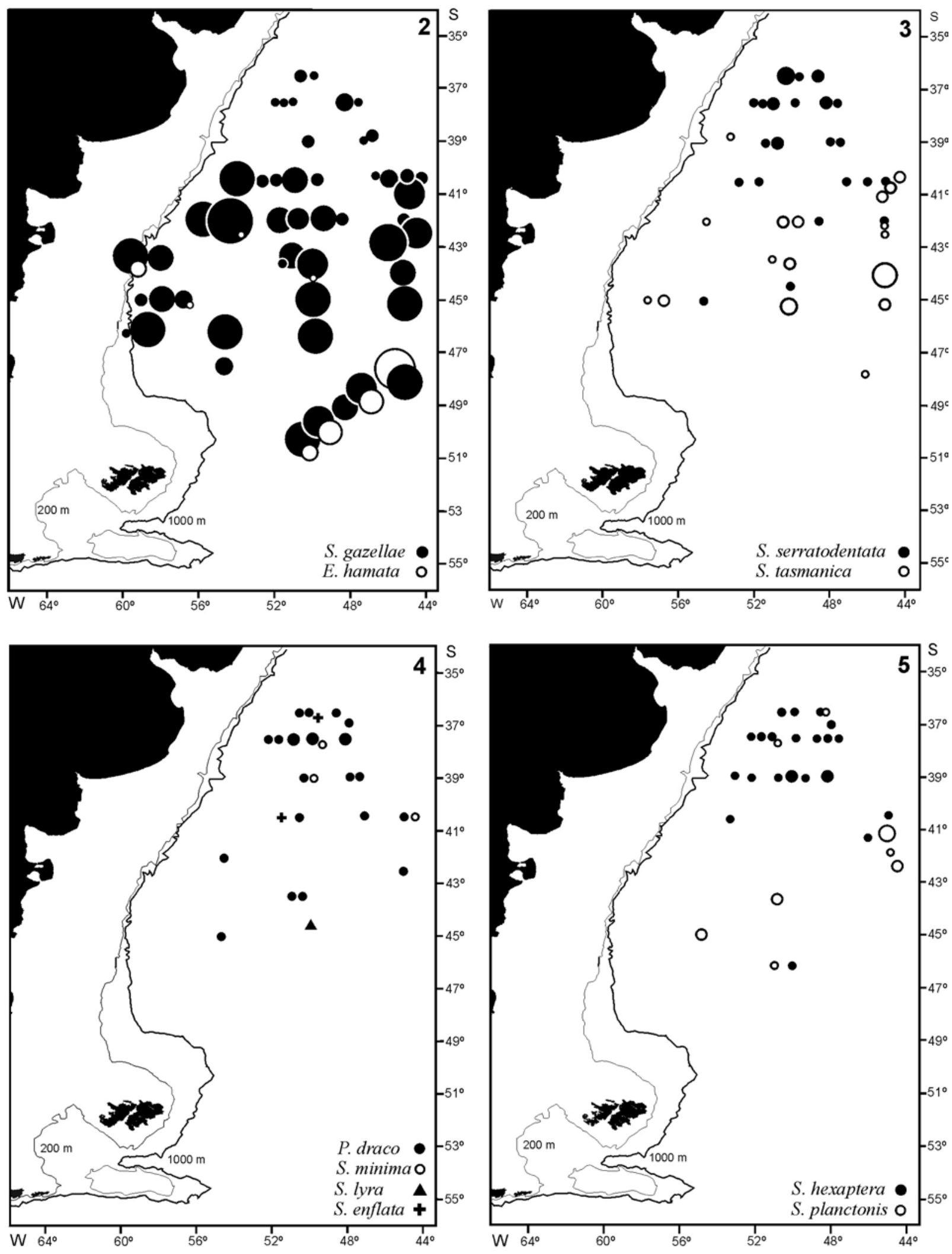

Figs. 2-5: Distribution and abundance of the chaetognath species from Brazil-Malvinas (Falkland) confluence zone (from August, $1^{\text {st }}$ through October, 24 $4^{\text {th }}$, 1988). 2: S. gazellae and E. hamata; 3: S. tasmanica and S. serratodentata; 4: P. draco, S. minima, S. lyra and S. enflata; 5: S. hexaptera and S. planctonis. Ind./1000 $\mathrm{m}^{3}$ :

$\Delta+1-9$ 50-99;

100-199; 
Table II. Presence and fidelity degrees between each species and each group (Ochiai-UPGMA). The probabilities of the positive significant associations $(\mathrm{p}<0,05)$ between species and group are in brackets; preferential species in bold; *, indicator species; **, exclusive species. S. lyra was found in a single outlier sample and is not indicated in the table.

\begin{tabular}{|c|c|c|c|c|c|c|}
\hline \multirow[b]{2}{*}{ Species } & \multicolumn{2}{|c|}{ A group } & \multicolumn{2}{|c|}{ B group } & \multicolumn{2}{|c|}{$\mathrm{C}$ group } \\
\hline & $\begin{array}{c}\text { Presence } \\
(\%)\end{array}$ & $\begin{array}{c}\text { Fidelity } \\
(\%)\end{array}$ & $\begin{array}{c}\text { Presence } \\
(\%)\end{array}$ & $\begin{array}{c}\text { Fidelity } \\
(\%)\end{array}$ & $\begin{array}{l}\text { Presence } \\
(\%)\end{array}$ & $\begin{array}{c}\text { Fidelity } \\
(\%)\end{array}$ \\
\hline Eukrohnia hamata & 0 & 0 & 0 & 0 & 23 & $100(0,0112) * *$ \\
\hline Pterosagitta draco & 70 & $70\left(3,6.10^{-5}\right)$ & 13 & 5 & 16 & 25 \\
\hline Sagitta gazellae & 75 & 31 & 25 & 4 & 100 & $65\left(1,8.10^{-5}\right)^{*}$ \\
\hline S. tasmanica & 0 & 0 & 0 & 0 & 45 & $100\left(4,2.10^{-6}\right)^{* *}$ \\
\hline S. serratodentata & 100 & $95\left(6,7.10^{-16}\right) *$ & 13 & 5 & 0 & 0 \\
\hline S. hexaptera & 70 & $64(0,0002)$ & 100 & $36(0,0001) *$ & 0 & 0 \\
\hline S. planctonis & 15 & 43 & 13 & 14 & 10 & 43 \\
\hline S. minima & 10 & $100 * *$ & 0 & 0 & 0 & 0 \\
\hline S. enflata & 10 & $100 * *$ & 0 & 0 & 0 & 0 \\
\hline
\end{tabular}

The clustering of sample units (s.u.) according to the Ochiai qualitative index and UPGMA yielded three groups: A, B and C (fig. 10). Two outlier s.u. (stations 14 and 107) were excluded from the clustering. At the same time, the clustering using the Bray-Curtis quantitative index and UPGMA yielded three groups, which significantly corresponded with the ones found through the qualitative index $\left(\mathrm{p}<1.10^{-7}\right)$. We preferred to use an index based on presence-absence data since such kind of indices generally produce more forceful results than quantitative ones, with regards to sampling biases and mistakes (GreEN, 1979). Moreover, the temporal or spatial dominance of a species or a small number of species does not involve changes in the qualitative composition of a community (Pérès \& PICARD, 1964).

The analysis of presence and fidelity degree of the groups obtained with the Ochiai index (tab. II) yielded: group A (20 s.u.) with $S$. serratodentata as the indicator species, $P$. draco and $S$. hexaptera as preferential species, and $S$. minima and $S$. enflata as exclusive species. Group B (9 s.u.) only had $S$. hexaptera as indicator species. Group C (32 s.u.) had $S$. gazellae as indicator species, and E. hamata and $S$. tasmanica as preferential and exclusive species.

The factorial analysis of multiple correspondences of the contingency table among the groups of s.u., which were found with the Ochiai index and UPGMA, and salinity and temperature yielded a biplot (fig.11), which indicates that: group A was associated to the highest temperatures and salinities (13 - $18.0^{\circ} \mathrm{C}$ and $35.4-36.2 \mathrm{psu}$ ); group B was also related to high temperatures and salinities; and group $\mathrm{C}$ was associated with the lowest temperatures and salinities in the studied area $\left(3-8.0^{\circ} \mathrm{C}\right.$ and 33.5 - 34.6 psu). From these analysis it can be concluded that group $\mathrm{C}$ is highly differentiated from groups $\mathrm{A}$ and $\mathrm{B}$. The differences between groups A and B may obey to the different proportions of slightly euryoecious species in both groups (best represented in A than in B). Sagitta hexaptera and P. draco were present in both groups, but A also included $S$. minima and $S$. planctonis. The relatively warm and saline conditions associated to groups A and B are related to waters influenced by the Brazil Current. The last conclusion allows us to consider groups A and B together, forming a great assemblage of stations associated to the same environmental (temperature and salinity) conditions. In contrast, the lower salinities and temperatures associated to group $\mathrm{C}$ would be typical of subantarctic waters.

Concerning $S$. gazellae, classified as an indicator species in group $\mathrm{C}$, its presence in the other groups again reveals its wide tolerance to environmental conditions. Therefore, it cannot be considered as an indicator species of subantarctic water masses. Since $S$. serratodentata, classified as an indicator species in group A, was not detected in the group associated to cold water conditions, it can be properly defined as an indicator species of subtropical water masses, as pointed out by DADON \& Boltovskoy (1982). The mapping of the groups according to Ochiai-UPGMA shows two well-differentiated areas (fig. 12), one made up by the stations of groups A and B, scattered in the northern region of the sampled area and related to subtropical water conditions, and another one made up by the stations of group $\mathrm{C}$, to the south and representing Subantarctic water conditions. The distribution of the different species of chaetognaths depends, among other factors, on the temperature and salinity of the water mass. Their highest densities are found under optimal development conditions, and decreased when approaching their distribution boundary. This fluctuation in density as well as in reproductive stages must be taken into account when determining the allocation range of the species. Accordingly, if specimens are found at very low densities or sterile, they might be considered expatriated organisms and may not reflect the real species range. In the area under analysis, the existence of species associated with higher temperatures and salinities (groups A and B), which were surrounded by species related to lower temperatures and salinities (group C), would indicate the presence of warm core eddies up to $46^{\circ} \mathrm{S}$ approximately, between September and October 1988 (fig. 12). These eddies would allow the presence of $P$. draco and $S$. hexaptera southward. The distribution patterns of the species detected confirm the hydrological complexity of the area analyzed. 

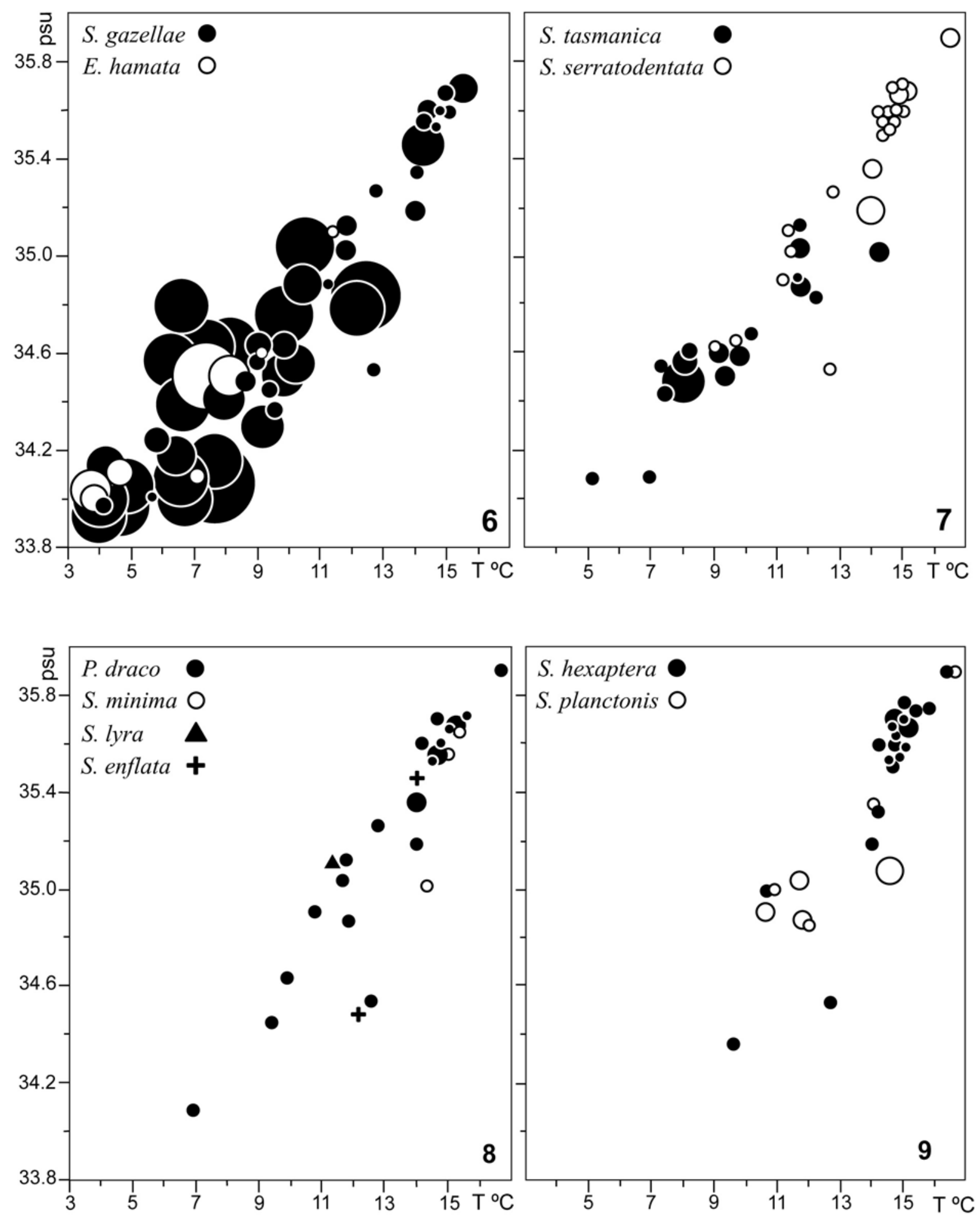

Figs. 6-9: Temperature-salinity-density (T-S-D) diagram of the chaetognath species from Brazil-Malvinas (Falkland) confluence zone (from August, $1^{\text {st }}$ through October, 24, 1988$)$. 6: S. gazellae and E. hamata; 7: S. tasmanica and S. serratodentata; 8: P. draco, S. minima, S. lyra and S. enflata; 9: S. hexaptera and S. planctonis. Ind./1000 $\mathrm{m}^{3}$ :

$\bullet+1-9 ; \bullet 10-49$

50-99;

100-199;

200-499; 


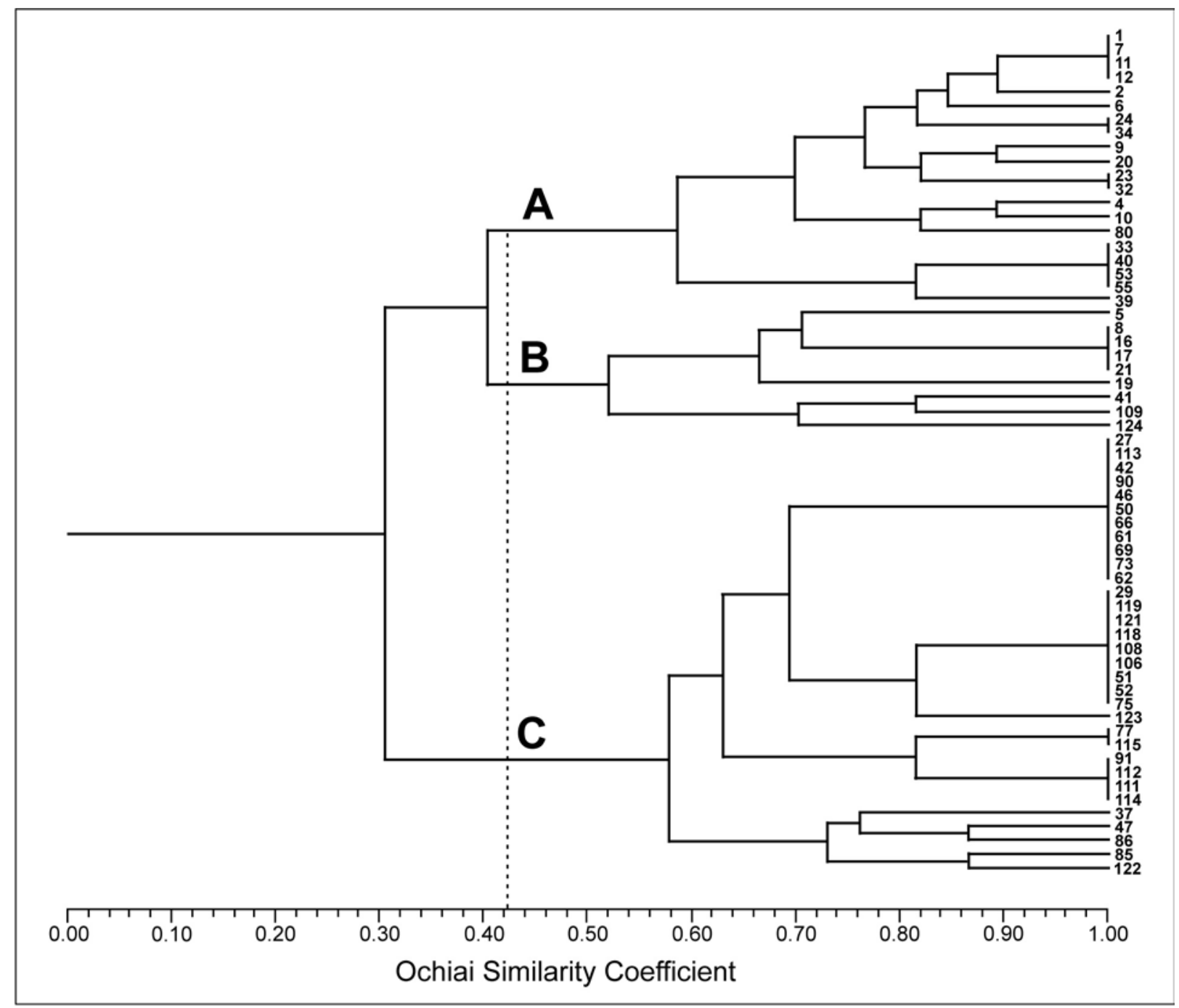

Fig. 10. Cluster analysis of sample units according to Ochiai index and UPGMA. Dot line: reference level.

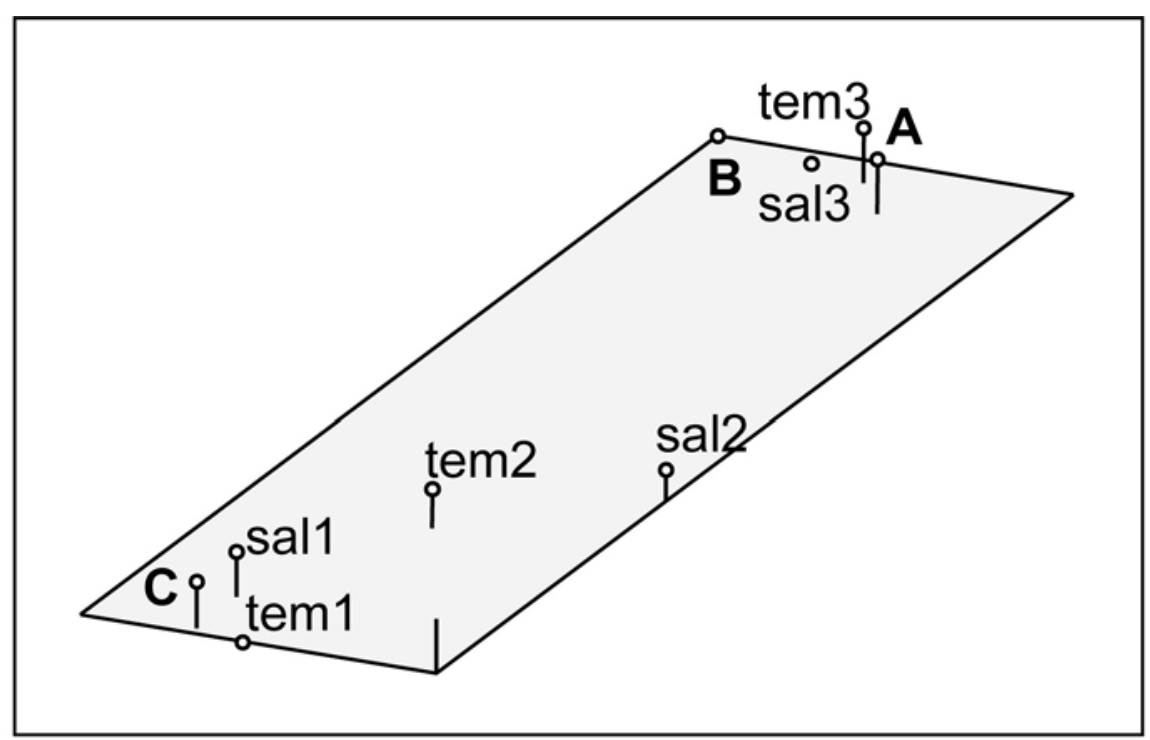

Fig. 11. Correspondence biplot among sample units groups (A, B and $\mathrm{C}$ ), temperature and salinity (tem $1,3.0-8.0{ }^{\circ} \mathrm{C}$; tem 2 , 8.0-13.0 ${ }^{\circ} \mathrm{C}$; tem3, 13.0-18.0 ${ }^{\circ} \mathrm{C}$; sal1, 33.5-34.6 psu; sal2, 34.6-35.4 psu; sal3, 35.4 - $36.2 \mathrm{psu}$ ). 


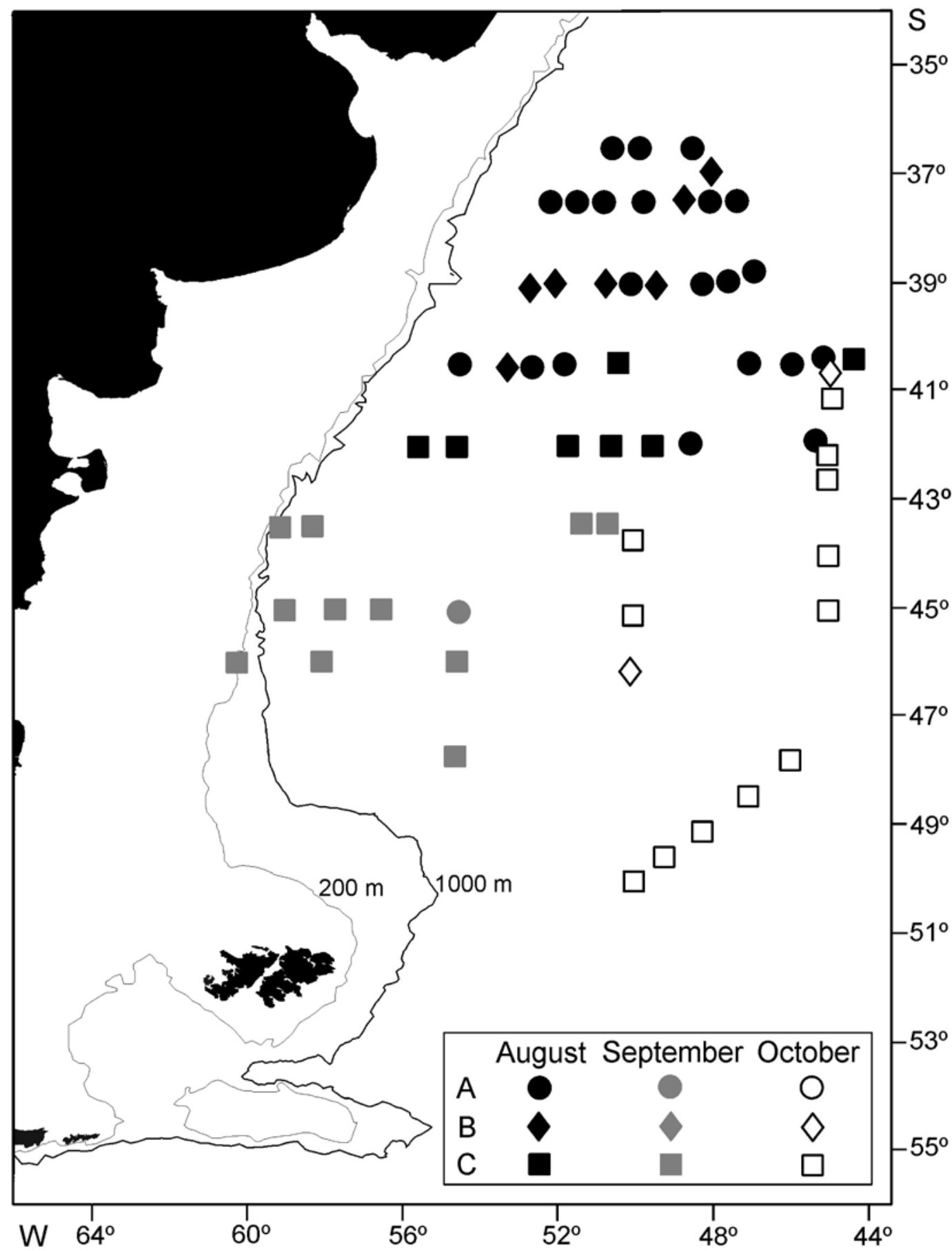

Fig. 12. Mapping of the sample unit groups (A, B, C) according to Ochiai-UPGMA in August, September and October 1988.

Acknowledgments. To Instituto Nacional de Investigación y Desarrollo Pesquero (INIDEP) from Mar del Plata, Argentina, for providing the material studied and H. E. Zaixso, for the statistic advice.

\section{REFERENCES}

Almeida Prado, M. S. 1961a. Chaetognatha encontrados em águas brasileiras. Boletim do Instituto Oceanográfico, Universidade São Paulo, São Paulo, 11(2):31-56.

1961b. Distribuição dos Chaetognatha no Atlântico Sul Occidental. Boletim do Instituto Oceanográfico, Universidade São Paulo, São Paulo, 11(4):15-49.

1963. Sobre o plancton da enseada do Mar Virado e os métodos de coletas. Boletim do Instituto Oceanográfico, Universidade São Paulo, São Paulo, 12(3):49-68.

1968. Distribution and annual occurence of Chaetognatha off Cananéia and Santos coast. Boletim do Instituto Oceanográfico, Universidade São Paulo, São Paulo, 17(1):33-55.

Alvariño, A. 1965. Chaetognaths. In: Barnes, H. ed. Oceanography and Marine Biology Annual Review. London, Allen \& Unwin. p.115-194.

1969. Los quetognatos del Atlántico. Distribución y notas esenciales de sistemática. Trabajos Instituto Español de Oceanografía, Madrid, 37:1-288.

Benzecri, J. P. 1976. L'analyse des données. 2. L'analyse des correspondances. Paris, Bordas. 609p. 
Bollmann, A. 1934. Die Chaetognathen der Deutschen Antarktischen Expedition auf der "Deutschland", 1911-1912. Internationale Revue der gesantem hydrobiologie und hydrographie, Leipzig, 30:251-305.

Boltovskoy, D. 1975a. Some biometrical, ecological, morphological and distributional aspects of Chaetognatha. Hydrobiologia, Dordrecht, 46(4):515-534.

1975b. Ecological aspects of zooplankton (Foraminifera, Pteropoda and Chaetognatha) of the Southwestern Atlantic Ocean. Veliger, Berkeley, 18(2):203-216.

1981. Chaetognatha. In: Boltovskoy, D. ed. Atlas del zooplancton del Atlántico sudoccidental y métodos de trabajo con el zooplancton marino. Mar del Plata, Instituto de Investigación y Desarrollo Pesquero. p.759-791.

Boltovskoy, D. \& Mostajo, E. 1974. Quetognatos del Mar Argentino y adyacencias. Consideraciones acerca de su utilización en calidad de indicadores hidrológicos. Physis, Buenos Aires, Secc. A, 33(86):239-255.

Boltovskoy, E. 1970. Masas de agua (característica, distribución, movimientos) en la superficie del Atlántico Sudoeste, según indicadores biológicosforaminíferos. Buenos Aires, Servicio de Hidrografía Naval. p.1-99. (Publicación H.643)

1981. Masas de agua en el Atlántico Sudoccidental. In: Boltovsкoy, D. ed. Atlas del zooplancton del Atlántico Sudoccidental y métodos de trabajo con el zooplancton marino. Mar del Plata, Instituto de Investigación y Desarrollo Pesquero. p.227-237.

Brandhorst, W. \& Castello, J. P. 1971. Evaluación de los recursos de anchoíta (Engraulis anchoita) frente a la Argentina y Uruguay. I. Las condiciones oceanográficas, sinopsis del conocimiento actual sobre la anchoíta y el plan para su evaluación. Contribución del Instituto de Biología Marina, Mar del Plata, 166:1-63.

Carrasco, J. L. \& Hernán, M. A. 1993. Estadística multivariante en las ciencias de la vida. Madrid, Editorial Ciencia 3. 363p.

Casanova, J-P. 1999. Chaetognatha. In: Boltovskoy, D. ed. South Atlantic Zooplankton. Leiden, Backhuys. v.2, p.1353-1374.

Ciotti, A. M.; Odebrecht, C. et al. 1995. Freshwater outflow and Subtropical Convergence influence on phytoplankton biomass on the southern Brazilian continental shelf. Continental Shelf Research, New Brunswick, 15(14):1737-1756.

Dadon, J. R. \& Boltovskoy, D. 1982. Zooplanktonic recurrent groups (Pteropoda, Euphausiacea, Chaetognatha) in the Southwestern Atlantic Ocean. Physis, Buenos Aires, Secc. A, 41(100):63-83.

David, P. M. 1955. The distribution of Sagitta gazellae RitterZahony. Discovery Reports, Cambridge, 27:235-278.

DigBy, P. G. N. \& Kempton, R. A. 1994. Multivariate analysis of ecological communities. London, Chapman \& Hall. 206p.

Feingenbaum, D. 1991. Food and feeding behaviour. In: Bone, Q., Kapp, H. \& Pierrot-Bults, A. C. eds. The biology of Chaetognaths. Oxford, Oxford University Press. p.45-55.

GAUCH, H. G. 1989. Multivariate analysis in community ecology. New York, Cambridge University. 298p.

Goni, G.; Kamholz, S. et al. 1996. Dinamics of the BrazilMalvinas Confluence based on inverted echo sounders and alimetry. Journal of Geophysical Research, Part C7, New Brunswick, 101:16273-16289.

Gordon, A. L. 1989. Brazil-Malvinas Confluence-1984. DeepSea Research, New Brunswick, 36:359-384.

Grant, G. C. 1991. Chaetognatha from the Central and Southern Middle Atlantic Bight: species composition, temperaturesalinity relationships, and interspecific associations. Fisheries Bulletin, Seatle, 89(1):33-40.

Green, R. H. 1979. Sampling design and statistical methods for environmental biologist. J. Wiley \& Sons, New York. $257 \mathrm{p}$.
Guerrero, R. A. \& Piola, A. 1997. Masas de agua en la plataforma continental. In: Boschi, E. E. ed. El Mar Argentino y sus recursos pesqueros. Antecedentes históricos de las exploraciones en el mar y las características ambientales. Mar del Plata, Instituto de Investigación y Desarrollo Pesquero. v.1, p.107-118.

Hair, J. F.; Anderson, R. E. et al. 1992. Multivariate analysis with readings. New York, MacMillan. 544p.

Legeckis, R. \& Gordon, A. L. 1982. Satellite observations of the Brazil and Falkland currents 1975 to 1976 and 1978. DeepSea Research, New Brunswick, 29:375-401.

Legendre, P. \& Legendre, L. 1998. Numerical ecology. Developments in environmental modelling 20 Amsterdam, Elsevier. 853p.

Liang, T. H. \& Vega-Pérez, L. A. 2001. Diversity and biomass of epiplanktonic chaetognath off south Atlantics western sector, from Cabo Frio $\left(23^{\circ} \mathrm{S}, 42^{\circ} \mathrm{W}\right)$ to São Pedro and São Paulo rocks $\left(01^{\circ} \mathrm{N}, 29^{\circ} \mathrm{W}\right)$. Oceánides, Mazatlán, 16(1):34-48.

McLelland, J. A. 1984. Observations on chaetognath distribution in the northeastern gulf of Mexico during the summer of 1974. Northeast Gulf Science, Savannah, 7:45-59.

Mazzoni, H. E. 1983. Abundancia y distribución de Chaetognatha en el Atlántico Sudoccidental (Mar Argentino). Physis, Buenos Aires, Secc. A, 41(101):157-171.

Mostajo, E. 1973. Quetognatos colectados en el Atlántico Sudoccidental entre los $44^{\circ} 44^{\prime}$ y $52^{\circ} 38^{\prime}$ de latitud sur. Neotrópica, La Plata, 19(59):94-100.

1976. Quetognatos de "Pesquería V". Su utilización como indicadores hidrológicos. Iheringia, Série Zoologia, Porto Alegre, (49):27-37

Pérès, J. M. \& Picard, J. 1964. Nouveaux manuel de bionomie benthique de la Mer Méditerranée. Recueil des travaux de la Station Marine d'Endoume, Marseille, 47:1-137.

Peterson, R. G. \& Stramma, L. 1991. Upper-level circulation in the South Atlantic Ocean. Progress in Oceanography, Great Britain, 26:1-73.

Pierrot-Bults, A. C. \& Nair, V. R. 1991. Distribution patterns in Chaetognatha. In: Bone, Q.; Kapp, H. \& Pierrot-Bults, A. C eds. The biology of Chaetognaths. Oxford, Oxford University. p.86-116.

Piola, A. R. \& Rivas, A. L. 1997. Corrientes en la plataforma continental. In: Boschi, E. E. ed. El Mar Argentino y sus recursos pesqueros. Antecedentes históricos de las exploraciones en el mar y las características ambientales. Mar del Plata, Instituto de Investigación y Desarrollo Pesquero, v. 1, p.119-133.

Provost, C.; Garcon, V. \& Falcon, M. 1996. Hydrographic conditions in the surface layers over the slope-open ocean transition area near the Brazil-Malvinas Confluence during austral summer 1990. Continental Shelf Research, New Brunswick, 16(2):215-235

ReEve, M. R. 1970. The Biology of Chaetognatha I. Quantitative aspects of growth and egg production in Sagitta hispida. In: Steele, J. H. ed. Marine food chains. Edinburgh, Oliver \& Boyd. p.168, 169 .

Sokal, R. R. \& Rohlf, F. J. 1997. Biometry. The principles and practice of statistics in biological research. New York, W. H. Freeman and Company. 887p.

Thiel, M. E. 1938. Die Chaetognathen bevolkerung des Sudatlantischen Ozean. Wissenschaftliche Ergebnisse der Deutsch. Atl. Exped."Meteor" 1925-1927, Leipzig, 13(1): $1-110$

Thomsen, H. 1962. Masas de agua características del Océano Atlántico. Buenos Aires, Servicio de Hidrografía Naval. p.122. (Publicación H.623)

Zaixso, H. E. 1996. Asociaciones de moluscos bentónicos submareales del Golfo San José y sur del Golfo San Matías (Chubut, Argentina). Physis, Buenos Aires, Secc. A, 54(126127):1-21. 